\title{
Manajemen POAC Wakaf Di Indonesia
}

\author{
Esti Alfiah $^{1}$, Mesi Herawati ${ }^{2}$, Riri Novitasari ${ }^{3}$ \\ ${ }^{1,2}$ Institut Agama Islam Negeri Bengkulu, Bengkulu, Indonesia \\ ${ }^{1}$ Email. esti.alfiah2107@gmail.com \\ ${ }^{2}$ Email. herawatimesi68@gmail.com \\ ${ }^{3}$ Email. ririnovitasari99@gmail.com
}

\begin{abstract}
A company succeeds if management is good. There are many reports of waqf land disputes on waqf institutions. That way it requires tracking the management of waqf management. Given, that the waqf institution is a public organization that certainly requires a good organizational system. Therefore, this journal discusses the management of waqf POAC in Indonesia. This research is a qualitative descriptive study. This is to explain and evaluate the management system in the management of waqf through management functions, namely Planning, Actuating, Organizing, and Controlling. Sources of data in this study come from literature, results of previous studies, and facts in the field found by the authors. In accordance with POAC Management that Waqf in Indonesia is not optimal. It can be seen from the planing that has not yet been realized, Organizing which is not optimal in assigning tasks, actuating is not optimal, it can be seen from the many reports of public complaints to the Indonesian Waqf Board and Controlling has not been done because it is only done when finding reports.
\end{abstract}

\section{Keywords : Management, POAC, Indonesia Waqf Board}

\section{Latar Belakang}

Indonesia merupakan sebuah negara dengan mayoritas penduduk Muslim terbesar yakni mencapai 207.176.162 atau 87\% dari total penduduk Indonesia 237.641.326. (Statistik, 2020) . Maka dari itu tidak heran jika semua elemen yang menyangkut Agama Islam sangat diminati, misalnya saja dari aspek ekonomi seperti perbankan, lembaga keuangan, asuransi, wakaf, zakat, bahkan perguruan tinggi sudah banyak menyediakan program studi keislaman. Salah satu instrumen penting dalam ekonomi Islam adalah wakaf, wakaf sendiri sudah ada sejak zaman Rasulullah SAW. Semua orang setuju amalan wakaf dalam Islam merupakan amalan yang selalu dijalankan dan diamalkan oleh para sahabat Nabi dan kaun muslimin sejak masa awal Islam hingga sekarang.

Wakaf di Indonesia mendapatkan perhatian masyarakat karena mampu memberikan manfaat kepada masyarakat sehingga wakaf menjadi amal sosial yang mampu memberikan manfaat kepada masyarakat banyak. Pada awalnya wakaf di Indonesia hanya dikelola sebagai amalan sosial, namun seiring berkembangnya zaman wakaf mengalami perubahan paradigma. Perubahan paradigma ini terutama dalam pengelolaan wakaf yang ditujukan untuk menyejahterakan umat muslim. Oleh karena itu,pendekatan wakaf yang digunakan adalah pendekatan bisnis dan manajemen. Konteks ini dikenal dengan wakaf produktif.

Selain perubahan dari tata pengelolaan wakaf, bentuk wakaf juga mengalami perubahan menyesuaikan dengan perkembangan zaman. Dari yang hanya berbentuk wakaf tanah, benda tidak bergerak sampai saat ini sudah berupa wakaf uang dan wakaf saham. Dilansir dari Kompas.com, potensi aset wakaf pertahun Rp 2.000 triliun dengan luas tanah wakaf mencapai 420 ribu hektare. Sementara potensi wakaf uang bisa menembus kisaran Rp 188 triliun per tahun. Saat ini potensi wakaf yang terealisasi baru Rp 400 miliar.(Kompas.com, 2019). Namun seiring dengan perkembangan wakaf, pengelolaan wakaf masih banyak mengalami kendala dan permasalahan yang muncul dikalangan masyarakat. Hal ini bisa kita lihat dari 
beberapa penelitian mengenai manajemen pengelolaan wakaf dan fakta di lapangan tentang pengelolaan wakaf. Permasalahan wakaf bisa kita lihat dari uraian berikut ini:

Pertama, banyaknya tanah wakaf yang tidak tersertifikat. Dari data yang terhimpun di sistem informasi wakaf KEMENAG (SIWAK), jumlah tanah wakaf yang terdaftar secara keseluruhan mencapai 381.912 lokasi tanah wakaf yang mencapai 51.252,76 hektare, sedangkan yang belum tersertifikasi ada 148.471 lokasi dengan luas 31.633,47 hektare. Dari data juga bisa kita lihat bahwa tanha wakaf masih dimanfaatkan secara konsep klasik yakni untuk pembangunan masjid dan mushollah. Seperti yang diilustrasikan dalam gambar berikut ini:

\section{Gambar 1}

Jumlah Tanah Wakaf Dan Pengalokasiannya
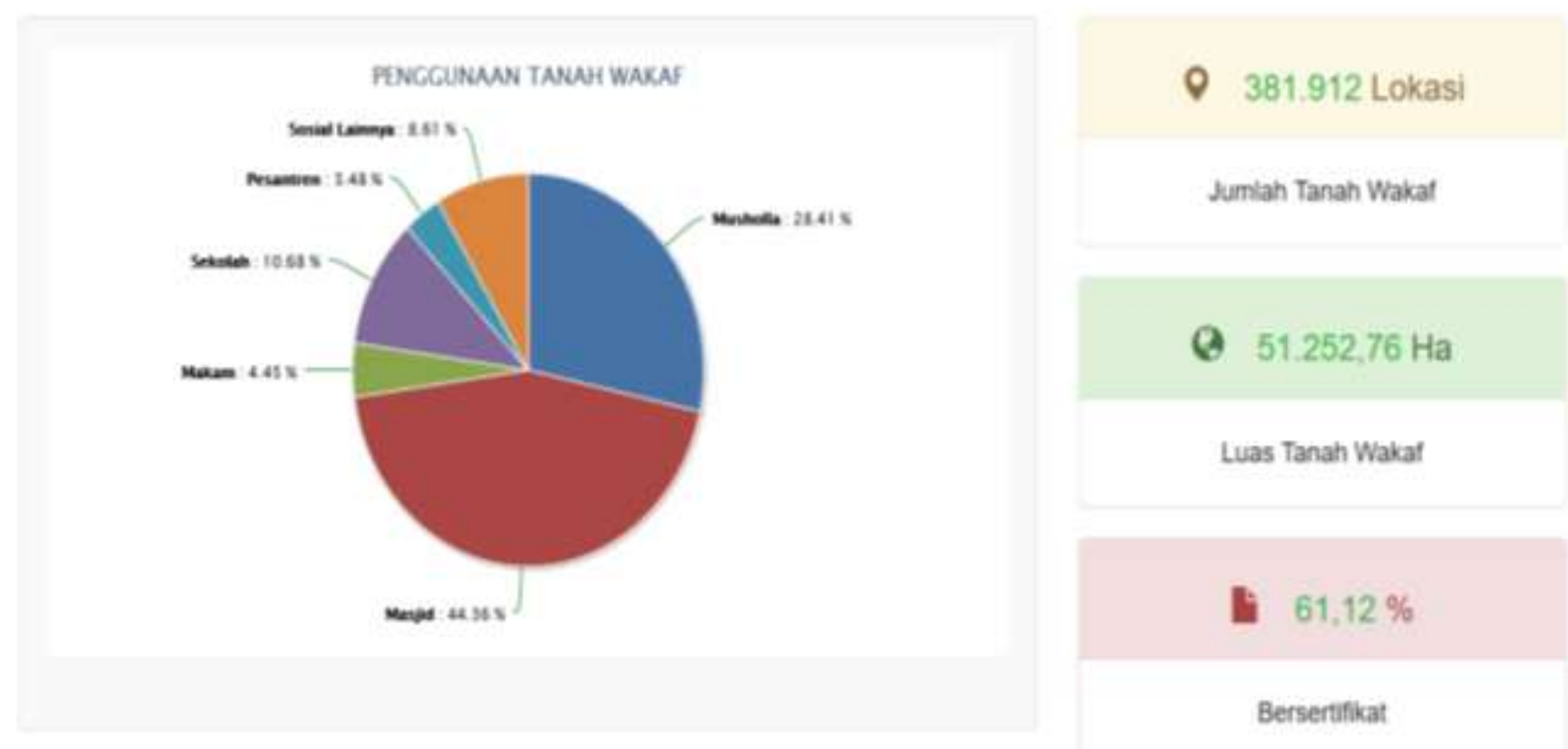

Sumber: Sistem Informasi Wakaf KEMENAG

Sedangkan untuk Provinsi Bengkulu sendiri jumalh tanah wakaf yang terdata adalah sebanyak 2.294 lokasi tanah wakaf dan dari jumlah tersebut, sebanyak 651 lokasi tanah yang tidak mempunyai sertifikat wakaf. Dengan rincian sebagai berikut:

Tabel 1

Data Tanah Wakaf Provinsi Bengkulu

\begin{tabular}{|c|c|c|c|c|c|c|c|}
\hline \multirow[b]{2}{*}{ No } & \multirow[b]{2}{*}{ Kantor Kementerian Agama } & \multirow[b]{2}{*}{ Jumlah } & \multirow{2}{*}{$\begin{array}{l}\text { Luas } \\
{[\mathrm{Ha}]}\end{array}$} & \multicolumn{2}{|c|}{ Sudah Sertifikat } & \multicolumn{2}{|c|}{ Belum Sertifikat } \\
\hline & & & & Jumlah & $\begin{array}{l}\text { Luas } \\
{[\mathrm{Ha}]}\end{array}$ & Jumlah & $\begin{array}{l}\text { Luas } \\
{[\mathrm{Ha}]}\end{array}$ \\
\hline 1. & KABUPATEN BENGKULU UTARA & 538 & 108,17 & 412 & 77,98 & 126 & 30,19 \\
\hline 2. & $\frac{\text { KABUPATEN BENGKULU }}{\text { SELATAN }}$ & 356 & 48,68 & 278 & 33,71 & 78 & 14,97 \\
\hline 3. & KABUPATEN REJANG LEBONG & 472 & 63,03 & 390 & 38,58 & 82 & 24,45 \\
\hline 4. & KOTA BENGKULU & 185 & 13,45 & 135 & 8,91 & 50 & 4,55 \\
\hline 5. & KABUPATEN MUKO-MUKO & 171 & 68,24 & 38 & 10,23 & 133 & 58,02 \\
\hline 6. & KABUPATEN KAUR & 136 & 30,81 & 32 & 16,16 & 104 & 14,65 \\
\hline
\end{tabular}




\begin{tabular}{||c|c|c|c|c|c|c|c|}
\hline 7. & KABUPATEN SELUMA & 125 & 25,65 & 125 & 25,65 & 0 & 0,00 \\
\hline \hline 8. & KABUPATEN BENGKULU TENGAH & 105 & 23,62 & 92 & 9,82 & 13 & 13,80 \\
\hline \hline 9. & KABUPATEN KEPAHIANG & 28 & 6,02 & 4 & 0,77 & 24 & 5,25 \\
\hline 10. & KABUPATEN LEBONG & 178 & 21,00 & 137 & 13,37 & 41 & 7,63 \\
\hline \hline
\end{tabular}

Sumber: Sistem Informasi Wakaf KEMENAG

Kedua, maraknya terjadi sengketa tanah wakaf oleh ahli waris. salah satunya adalah kasus yang diangkat dalam penelitian oleh Ahmad Fauzi yang membahas tentang penyelesaian sengketa hak atas tanah wakaf di luar pengadilan oleh kepala dusun. Kasus ini terjadi di kecamatan semidang alas maras kabupaten seluma provinsi bengkulu. (Fauzi, 2014). Bahkan pada Februari 2019 Presiden Joko Widodo membagikan 25 sertifikat wakaf di Provinsi Bengkulu, sebagai upaya untuk menghindari terjadinya sengketa wakaf lahan masjid.(Moerti, 2019).

Maka, untuk meminimalisir terjadinya sengketa tanah wakaf diperlukan penelusuran manajemen pengelolaan wakaf. Mengingat, bahwa lembaga wakaf merupakan sebuah organisasi publik yang tentu memerlukan sistem pengorganisasian yang baik. Dalam ilmu manajemen organisasi merupakan tempat berlangsungnya fungsi manajemen. Menurut G.R Terry dalam Winardi bahwa fungsi manajemen merupakan serangkaian bagian dalam menyusun pada manajemen sehingga bagian-bagian tersebut dapat melaksanakan fungsi dalam mencapai tujuan organisasi. Fungsi-fungsi manajemaen terdiri dari: Perencanaan (Planning), pengorganisasian (Organizing), penggerakan (Actuating), dan pengawasan (Controlling) (George R. Terry dan Leslie W. Rue, 2019).

Penerapan sistem manajemen sangat menentukan arah dan keberhasilan suatu organisasi. Sebab kesuksesan suatu organisasai sangat tergantung pada efisiensi dan efektivitas manajemen organisasi tersebut. Maka, dari uraian diatas perlu dianalisis manajemen pengelolaan wakaf dari fungsi-fungsi manajemen, sehingga bisa diidentifikasi fungsi manajemn pada organisasi pengelolaan wakaf.

\section{Teori dan Metode}

\subsection{Manajemen POAC}

Manajemen berasal dari kata management, berawal dari kata "to manage" yang artinya tata laksana atau mengurus atau ketatalaksanaan. Manajemen adalah mengatur, membimbing dan memimpin karyawannya supaya usaha yang sedang dikerjakan mencapai tujuan, perilaku ini dilakukan oleh seorang manajer (Mappasiara, 2018:76)

Manajemen dalam bahasa Arab disebut Idarah. Idarah diambil berasal dari kata addauran. Sebagian pengamat secara istilah mengartikannya sebagai alat untuk mewujudkan tujuan umum. (Nizar, 2018)

Bahwa idarah (manajemen) adalah suatu aktivitas yang terkait kepemimpinan, pengarahan, pengembangan personal, perencanaan dan pengawasan terhadap pekerjaan yang berkenaan dengan unsur-unsur pokok dalam suatu proyek.

Manajemen adalah suatu proses atau kerangka yang melibatkan bimbingan atau pengarahan suatu kelompok orang-orang kearah tujuan-tujuan organisasional atau maksudmaksud yang nyata. Manejemen adalah suatu kegiatan, pelaksanaannya adalah pengelolaan, sedang pelaksananya disebut manager atau pengelola (George R. Terry dan Leslie W. Rue, 2019). 
Manajemen juga merupakan ilmu pengetahuan maupun seni. Seni adalah pengetahuan bagaimana mencapai hasil yang diinginkan. Seni ialah kecakapan yang diperoleh dari pengamatan dan pelajaran serta kemampuan untuk menggunakan pengetahuan manajemen. Seni manajemen menghendaki kreatifitas, atas dasar dan dengan syarat suatu pengertian mengenai ilmu manajemen. Maka karena itu ilmu pengetahuan dari seni manajemen saling melengkapi dan seimbang diantara keduanya (George R. Terry dan Leslie W. Rue, 2019).

Manajemen pada dasarnya belum memiliki perngertian yang baku namun dengan tujuan yang sama yaitu tercapainya tujuan perusahaan. Meski demikian, memiliki pokok pengertian yang sama. Ada beberapa definisi menurut para ahli tentang management.

Menurut Marry Parker Foller mangement is the art of getting this done throught people. Manajemen merupakan seni dalam mencapai tujuan melalui orang lain. Slanjutnya James A.F. Stoner Management is the process of planning, organizing, leading, and controlling the effort of organization member and using all other organizational resources to achieve stated organizational goals. Manajemen ialah proses perencanaan, organisasi, kepemimpinan dan pengawasan terhadap usaha-usaha anggota organisasi dan penggunaan semua sumber-sumber organisasi lainnya untuk mencapai tujuan organisasi yang telah ditetapkan. Kemudian, Luther Gulick Manajemen menjadi suatu bidang pengetahuan (ilmu) yang secara sistematik berusaha memahami mengapa dan bagaimana orang bekerja sama. Dan terakhir, menurut Robert L. Kats mengutip dari sulastri manajemen merupakan suatu profesi yang menuntut persyaratan tertentu, seorang manajer harus memiliki tiga keahlian atau kemampuan hakiki, yaitu kompetensi secara konseptual, sosial (hubungan manusiawi), dan teknikal.(Kamal, 2019)

Keempat defenisi di atas mencerminkan kecairan defenisi dari manajemen itu sendiri. Tidak ada defenisi yang baku yang disetujui oleh para ahli tentang manajemen. Follet misalnya menyebutkan manajemen sebagai seni (kiat), Stoner mengatakan manajemen sebagai ilmu, sedangkan manajemen menurut Kats sebagai sebuah profesi.(Kamal, 2019)

Dapat disimpulkan bahwa manajemen adalah proses yang dilakukan oleh sebuah badan atau perusahaan untuk mencapai tujuan bersama dengan melakukan kegiatan atau tindakan yang akan dilakukan dengan empat fungsi utama, yaitu: perencanaan, pengorganisasian, pergerakan dan pengawasan.

Fungsi manajemen mencakup 4 hal yaitu: Planning, Organizing, Actuating dan Controlling. Pertama, Perencanaan atau planning adalah proses yang menyangkut upaya untuk merumuskan tujuan yang akan dicapai dimasa mendatang, tindakan-tindakan yang perlu dijalankan untuk mencapai tujuan yang telah ditentukan dan menentukan dana yang diperlukan dan faktor-faktor produksi lain yang akan digunakan (George R. Terry dan Leslie W. Rue, 2019).

Menurut Wilson, dalam (Sarinah, 2017: 38), Pengertian Perencanaan merupakan salah satu proses lain, atau merubah suatu keadaan untuk mencapai maksud yang dituju oleh perencanaan atau oleh orang/badan yang di wakili oleh perencanaan itu. Perencanaan itu meliputi: Analisis, kebijakan dan rancangan. Perencanaan adalah proses dasar di mana manajemen memutuskan tujuan dan cara mencapainya. Sebelum sesorang dapat mengorganisir, mengendalikan, ataupun memimpin, maka ia harus terlebih dahulu membuat rencana-rencana yang memberikan tujuan dan arah suatu kelompok atau kegiatan.(Kamal, 2019:356)

Menurut Wilson ini jelaskan lebih rinci dalam buku direktorat Jenderal bahwa langkahlangkah perencanaannya yaitu menetapkan visi dan misi yang jelas, mewaspadai dan memperhatikan lingkungan eksternal yang berpengaruh pada organisasi, serta peluang dan ancaman atau penghalang yang ada dilingkungan luar, menetapkan keuangan dan sumber lainnya yang akan diperlukan untuk melaksanakan rencana, menentukan sebuah bingkai waktu dan mengukur keberhasilan, target-target untuk mencapai tujuan, orang yang 
bertangung jawab dan memonitoring. (Direktorat Jenderal Bimbingan Masyarakat Islam, 2012)

Kedua, Organizing atau dalam bahasa Indonesia pengorganisasian merupakan proses menyangkut bagaimana strategi dan taktik yang telah dirumuskan dalam perencanaan yang didesain dalam struktur organisasi yang tepat dan tangguh. Pengorganisasian adalah seluruh kegiatan dalam proses pengelompokan orang, tugas, tanggung jawab serta wewenang sehingga tujuan organisasi tercapai (Dakhi, 2016). Pengorganisasian meliputi masing-masing pihak diberikan tugas terpisah, membentuk bagian, mendelegasikan dan menetapkan sistem komunikasi, serta setiap karyawan dikordinir dalam satu tim yang solid dan terorganisir (George R. Terry dan Leslie W. Rue, 2019).

Selain itu pengorganisasian juga merupakan penentuan pekerjaan yang harus dilakukan, pengelompokan tugas dan membagi tugas kepada setiap karyawan. Tujuan dari pengorganisasian ini adalah untuk menetapkan peran serta struktur dimana karyawan dapat mengetahui apa tugas dan tujuan mereka. Sehingga dapat disimpulkan bahwa pengorganisasian adalah sistem yang dibentuk untuk membagi atau mengelompokkan setiap lini dalam organisasi sehingga organisasi dapat dijalankan oleh orang-orang yang berkompeten di bidangnya masing-masing. Sehingga visi dan misi organisasi dapat tercapai.

Perangkat yang baik dibutuhkan dalam mengurus suatu lembaga. Perangkat tersebut merupakan aktor dominan yang menetukan keberhasilan. Ibarat mengelolah masakan, tanpa didukung oleh perangkat seperti peralatan yang layak, kemampuan koki dan api yang bagus mustahil diperoleh masakan yang lezat. Kelengkapan peralatan masak dan kemampuan koki dalam mengelola bahan-bahan menjadi unsur penentu keberhasilan memasak. Begitu pula dengan keberadaan suatu lembaga pengelola zakat, untuk menjalankan fungsinya secara maksimal maka perlu didukung infrastruktur yang cukup, disamping kemampuan manajerial yang baik. Ada tiga kunci yang dapat dipakai untuk menguji profesionalisme tersebut yaitu amanah, profesional dan transparansi.(Direktorat Jenderal Bimbingan Masyarakat Islam, 2012)

Ketiga, Actuating atau pergerakan adalah cara membuat orang lain melaksanakan tugasnya, mendorong dan memotivasi bawahannya, serta menciptakan suasana yang kondusif, sehingga timbul pengertian dan kepercayaan yang baik. Apabila perencanaan, pengorganisasian sudah ada maka fungsi pergerakan sudah dapat dilakukan untuk dapat merealisir tujuan organisasi, lembaga dan sejenisnya. Pergerakan merupakan suatu proses pengarahan dan mempengaruhi karyawan agar mampu bekerjasama dan bertanggung jawab dengan antusiasme dan efektif dalam mencapai tujuan organisasi secara umum tujuan pengarahan yang ingin dicapai pada setiap kegiatan adalah membina disiplin kerja, dan memotivasi yang terarah. Kegiatan mengarahkan dan mempengaruhi ini mencakup empat kegiatan penting yaitu: penyuluhan, pelatihan, bimbingan dan motivasi. Pergerakan ini merupakan fungsi terpenting dalam manajemen karena bagaimanapun juga modernnya peralatan tanpa adanya sumber daya manusia tidak dapat apa-apa (George R. Terry dan Leslie W. Rue, 2019).

Pergerakkan biasanya dikatakan sebagai kegiatan manajemen yang paling menantang dan paling penting karena langsung berhadapan dengan manusia. Bagaimana membuat orang lain bekerja untuk tujuan organisasi merupakan pekerjaan yang tidak mudah. Manajer harus mampu menciptakan suasana (atmosfer) yang bisa mendorong orang untuk bekerja. Cara yang dipakai mungkin sangat berlainan dari satu organisasi ke organisasi lain.(Kamal, 2019:358)

Keempat, Controlling atau fungsi pengawasan. Mengutip dari sarinah, Elemen terakhir proses manajemen adalah pengendalian. System pengawasan harus dibuat sebaik mungkin dan komprehensif. Disamping Control by System, seorang pemimpin harus memberikan warning kepada bawahannya terhadap situasi kerja yang sudah tidak sesuai dengan yang 
direncanakan. Controlling atau pengawasan dan pengendalian (wasdal) adalah proses untuk mengamati secara terus menerus pelaksanaan kegiatan sesuai dengan rencana kerja yang sudah disusun dan mengadakan koreksi jika terjadi. Controlling atau pengawasan adalah fungsi manajemen dimana peran dari personal yang sudah memiliki tugas, wewenang dan menjalankan pelaksanaannya perlu dilakukan pengawasan agar supaya berjalan sesuai dengan tujuan, visi dan misi perusahaan (Sarinah, 2017:70,105).

Pengendalian bertujuan melihat apakah kegiatan organisasi sesuai dengan rencana. Manajer harus selalu memonitor kemajuan organisasi. Fungsi pengendalian meliputi empat kegiatan: (1) menentukan standar prestasi, (2) mengukur prestasi yang telah dicapai selama ini, (3) membandingkan prestasi yang telah dicapai dengan standar prestasi, dan (4) melakukan perbaikan jika ada penyimpangan dari standar prestasi yang telah ditentukan. Kemudian, kembali lagi ke fungsi perencanaan untuk periode berikutnya.(Kamal, 2019:358)

Pengawasan juga bisa dibedakan menurut sifat dan waktunya adalah pertama, Preventif Control adalah pengawasan yang dilakukan sebelum pengawasan dilakukan untuk menghindari terjadinya penyimpangan dalam pelaksanaanya. Pengawasan ini merupakan pengawasan terbaik karena dilakukan sebelum terjadi kesalahan namun sifatnya prediktif. Kedua, Repressive Control adalah pengawasan yang dilakukan setelah terjadinya kesalahan dalam pelaksanaanya. Dengan maksud agar tidak terjadinya pengulangan kesalahan, sehingga hasilnya sesuai dengan yang diinginkan. Ketiga, Pengawasan saat proses dilakukan sehingga dapat segera dilakukan perbaikan. Keempat, Pengawasan berkala adalah pengawasan yang dilakukan secara berkala, misalnya perminggu, perbulan dan lainnya. Kelima, Pengawasan mendadak (sidak) adalah pengawasan yang dilakukan secara mendadak untuk mengetahui apa pelaksanaanya dilakukan dengan baik atau tidak. Keenam, Pengawasan melekat (waskat) adalah pengawasan atau pengendalian yang dilakukan secara integratif mulai dari sebelum, pada saat, dan sesudah kegiatan dilakukan.

\subsection{Wakaf dan Pengelolaan Wakaf}

Menurut bahasa wakaf berasal dari bahasa Arab yaitu Waqafa artinya berhenti di tempat. Dikatakan menahan karena tanah yang telah diwakafkan ditahan dari kerusakan, penjualan dan dijaga supaya tidak dipergunakan kepada semua hal yang tidak sesuai dengan tujuan wakaf (Jubaedah, 2017:256). Menurut Didin Hafidhuddin, banyak hikmah dan manfaat yang dapat diambil dari kegiatan wakaf, baik bagi wakif maupun bagi masyarakat secara lebih luas, antara lain yaitu menunjukkan kepedulian dan tanggung jawab terhadap kebutuhan masyarakat. Keuntungan moral bagi wakif dengan mendapatkan pahala yang akan mengalir terus,walaupun wakif sudah meninggal dunia. Memperbanyak asset-aset yang digunakan untuk kepentingan umum yang sesuai dengan ajaran Islam merupakan sumber dana potensial bagi kepentingan peningkatan kualitas umat, seperti pendidikan, kesehatan, kesejahteraan dan sebagainya (Jubaedah, 2017: 268). Sedangkan secara istilah menurut UU tentang wakaf, wakaf adalah perbuatan hukum wakif untuk memisahkan dan/atau menyerahkan sebagian harta benda miliknya untuk dimanfaatkan selamanya atau untuk jangka waktu tertentu sesuai dengan kepentingannya guna keperluan ibadah dan/atau kesejahteraan umum menurut syari'ah.(Jubaedah, 2017:268-269)

Wakaf sendiri sudah dikenal sejak masa Rasulullah SAW, karena wakaf disyari'atkan pada tahun kedua hijriyah yakni saat sesudah Nabi SAW pindah ke Madinah. Menurut sebagian pendapat bahwa yang pertama kali melaksanakan wakaf adalah Rasulullah SAW, yaitu Nabi mewakafkan tanah miliknya untuk dibangun masjid. Sedangkan sebagian ulama yang lain berpendapat bahwa yang pertama kali melaksanakan wakaf adalah sayyidina Umar Bin Khattab, kemudian syari'at wakaf yang telah dilakukan oleh Umar Bin Khattab 
diteruskan oleh Abu Thalhah yang mewakafkan kebun kesayangannya yakni kebun "Baihara". Setelah itu baru disusul oleh sahabat-sahabat Nabi yang lain (Khusaeri, 2015).

Secara umum harta benda yang bisa diwakafkan dibagi menjadi dua yaitu benda tidak bergerak dan benda bergerak. Benda tidak bergerak bisa berupa tanah, bangunan, tanaman, atau benda tidak bergerak lainnya. Sedangkan benda bergerak yaitu berupa uang, logam mulia, surat berharga, kendaraan, hak sewa, dan benda bergerak lainnya sesuai dengan peraturan UU yang berlaku (Jubaedah, 2017).

Dalam pengelolaan wakaf, sangat erat kaitannya dengan nadzir wakaf. Dalam hal pengelolaan wakaf, nadzirlah yang sangat berperan penting. Setelah tanah wakaf didaftarkan di PPAIW, maka dalam pengelolaan tanah wakaf tersebut nadzir harus memperhatikan beberapa hal sebagai berikut:(P. R. Indonesia, 2004). Pertama, memberi perlindungan terhadap tanah wakaf dengan memberi sertifikat tanah wakaf, hal ini harus segera dilakukan agar tanah-tanah wakaf tersebut tidak jatuh ke pihak yang tidak berhak. Kedua, mengelola dan mengembangkan harta wakaf sesuai dengan prinsip syariah dan secara produktif. Ketiga, pengelolaan dan pengembangan harta wakaf memerlukan perlindungan dari lembaga penjamin syariah. Keempat, dalam mengelola dan mengembangkan harta wakaf nadzir dilarang melakukan perubahan peruntukan harta benda wakaf kecuali atas izin tertulis dari BWI. Kelima, izin perubahan peruntukan harta wakaf hanya dapat diberikan jika harta benda wakaf tidak bias dipergunakan sesuai dengan peruntukannya dalam ikrar wakaf.

Kelembagaan wakaf dinaungi pada saat lahirnya Undang-Undang Nomor 41 tahun 2004 tentang wakaf merupakan salah satu upaya untuk memberikan payung hukum yang diharapkan dapat mendorong pengembangan perwakafan di Indonesia. peraturan pelaksanaan lembaga wakaf mengacu pada Undang-undang wakaf dan peraturan Badan Wakaf Indonesia. Secara rinci tugas dan wewenang lembaga wakaf dijelaskan adalah pertama, melakukan pembinaan terhadap nazhir dalam mengelola dan mengembangkan harta benda wakaf. Kedua, melakukan pengelolaan dan pengembangan harta benda wakaf berskala nasional dan internasional. Ketiga, memberikan persetujuan dan atau izin atas perubahan peruntukan dan status harta benda wakaf. Keempat, memberhentikan dan mengganti nazhir. Kelima, memberikan persetujuan atas penukaran harta benda wakaf. Dan terakhir Memberikan saran dan pertimbangan kepada pemerintah dalam penyusunan kebijakan di bidang perwakafan. (B. W. Indonesia, 2020)

Kemudian, melalui Peraturan BWI Nomor 1 Tahun 2007 tentang Organisasi dan Tata Kerja Badan Wakaf Indonesia, tugas dan wewenangnya lembaga wakaf adalah melakukan pembinaan terhadap nazhir dalam mengelola dan mengembangkan harta benda wakaf, membuat pedoman pengelolaan dan pengembangan harta benda wakaf, melakukan pengelolaan dan pengembangan harta benda wakaf berskala nasional dan internasional serta harta benda wakaf terlantar, memberikan pertimbangan, persetujuan, dan/atau izin atas perubahan peruntukan dan status harta benda wakaf, memberikan pertimbangan dan/ atau persetujuan atas penukaran harta benda wakaf, memberikan saran dan pertimbangan kepada Pemerintah dalam penyusunan kebijakan dibidang perwakafan, menerima, melakukan penilaian, menerbitkan tanda bukti pendaftaran nazhir, dan mengangkat kembali nazhir yang telah habis masa baktinya, memberhentikan dan mengganti nazhir bila dipandang perlu, memberikan saran dan pertimbangan kepada Menteri Agama dalam menunjuk Lembaga Keuangan Syariah Penerima Wakaf Uang (LKS-PWU) dan menerima pendaftaran Akta Ikrar Wakaf (AIW) benda bergerak selain uang dari Pejabat Pembuat Akta Ikrar Wakaf (PPAIW). (B. W. Indonesia, 2018) 


\subsection{Metode Penelitian}

Penelitian ini merupakan penelitian deskriptif kualitatif. Yang bersifat menjelaskan dan mengevaluasi sistem manajemen dalam pengelolaan wakaf melalui fungsi-fungsi manajemen yaitu Planning, Actuating, Organizing, dan Controlling. Sumber data pada penelitian ini berasal dari pustaka, hasil penelitian terdahulu dan fakta di lapangan yang ditemukan oleh penulis.

\section{Hasil dan Pembahasan}

\subsection{Manajemen POAC Wakaf}

Planning dapat di artikan menyusun rencana untuk mencapai tujuan yang ingin di capai. Merencanakan berarti mengupayakan dan memaksimalkan penggunaan sumber daya manusia, sumber daya alam, dan sumber daya lainnya untuk mencapai tujuan organisasi.(Suhairi, 2015) Perencanaan wakaf yang diaungi oleh Badan Wakaf Indonesia jika dilihat dari sistem yang ditetapkan oleh BWI, manajemen perencanaan ini telah dirancang sedemikian rupa untuk mencapai tujuan dari wakaf. Hal ini terlihat dari struktur organisasi yang ditetapkan oleh BWI mulai dari tingkat Nasional hingga paling bawah yaitu pada tingkat kecamatan. Selain itu menurut buku pedoman yang diterbitkan oleh Bimas Islam, manajemen perencanaan dilihat dari beberapa sisi sebagai berikut:

a. Menetapkan visi dan misi yang jelas. Untuk menetapkan ini, langkah terlebih dahulu adalah mendefinisikan tujuan organisasi untuk menemukan arah dan menentukan tujuan strategisnya (Shulthoni, Saad, Kayadibi, \& Ariffin, 2018). Sehingga Visi dan Misi terwujud. Tujuan BWI adalah membina nazhir agar aset wakaf dikelola lebih baik dan lebih produktif sehingga bisa memberikan manfaat lebih besar kepada masyarakat, baik dalam bentuk pelayanan sosial, pemberdayaan ekonomi, maupun pembangunan infrastruktur publik (B. W. Indonesia, 2020). Badan wakaf Indonesia memiliki Visi dan Misi sebagai berikut:

Gambar 2

Visi dan Misi Badan Wakaf Indonesia

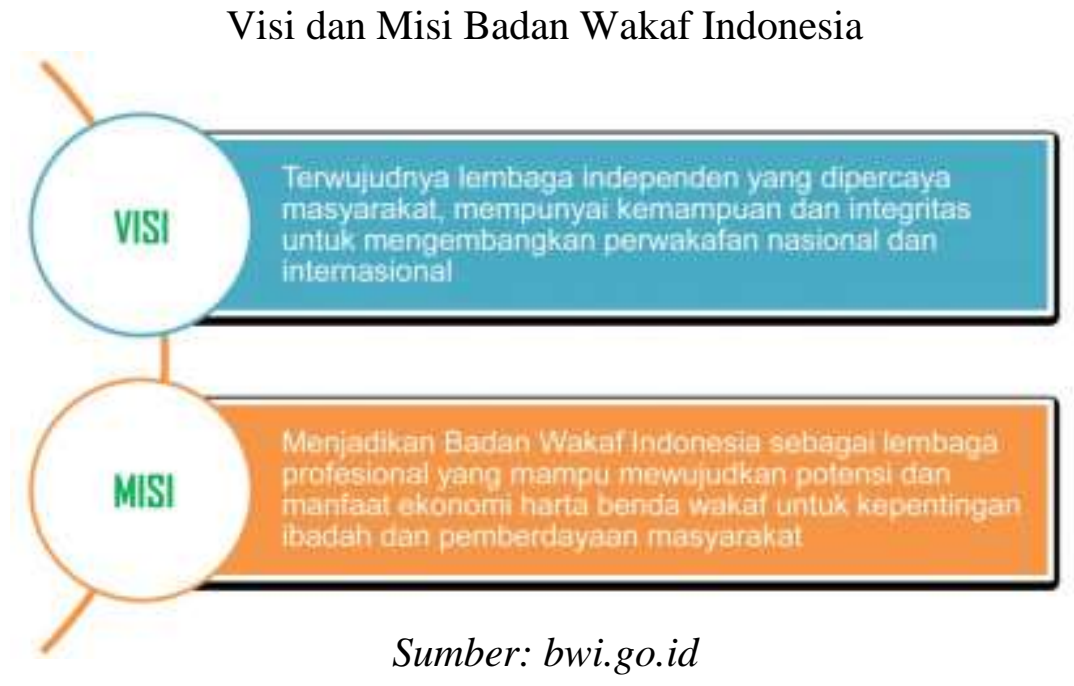

Namun, apakah visi itu dijalankan, jika dilihat dari berbagai permasalahan yang dihadapi oleh BWI sebelumnya, maka bisa kita simpulkan bahwa Visi dan Misi BWI belum terwujud secara optimal. Hal ini bisa kita lihat dari masalah tanah wakaf yang belum dikelola secara optimal, dari permasalahan sengketa tanah wakfa, dan juga masalah tanah wakaf yang belum tersertifikasi. 
b. Menetapkan anggaran untuk melaksanakan rencana. Pada point ini BWI masih mempunyai banyak kendala dalam hal anggaran. Hal ini terlihat dari banyaknya permasalahan wakaf yang ditimbulkan akibat dari kurangnya anggaran dalam pengelolaan wakaf. Hal ini juga diperkuat oleh penelitian dari Nurul Huda yang menyebutkan bahwa prioritas masalah wakaf salah satunya adalah minimnya biaya APBN untuk sertifikasi wakaf.(Huda, Rini, Mardoni, Anggraini, \& Hudori, 2016) Sehingga menyebabkan banyak tanah wakaf yang belum tersertifikasi, hal ini tentu juga akan menghambat proses pengelolaan wakaf itu sendiri.

c. Pandangan masyarakat terhadap organisasi. Padangan masyarakat terhadap organisasi wakaf tentu tidak terlepas dari pandangan masyarakat terhadap wakaf. Dalam hal ini mayoritas masyarakat Indonesia masih memahami wakaf dengan konsep klasik, yaitu wakaf merupakan harta milik Allah yang tidak boleh diubah ataupun diganggu gugat. Sehingga menyebabkan kesulitan dalam mengembangkan harta wakaf dengan jalan produktif. Hal ini juga didukung oleh banyaknya tanah wakaf yang diperuntukkan hanya untuk masjid dan musholla yang mencapai 72,77\%.(Agama, 2020) Selain itu masyarakat Indonesia memiliki literasi yang masih minim terhadap wakaf, terutama wakaf produktif. Dari hasil pengamatan, masyarakat belum mengenal baik tentang lembaga Badan Wakaf Indonesia,(Herawati, 2020) hal ini juga diperkuat oleh penelitian Nurul Huda yang menyebutkan bahwa sosialisasi Undang-undang wakaf kepada masyarakat yang masih kurang serta masih rendahnya koordinasi BWI dengan instansi yang terkait dengan wakaf. (Huda et al., 2016)

d. Mengidentifikasi kekuatan dan kelemahan organisasi kita, serta peluang dan ancaman atau penghalang yang ada dilingkungan luar. Lembaga ini belum pernah mengidentifikasi perihal tersebut. Namun mereka hanya review dari hasil artikel yang sudah terbit. Ada beberapa review dari pihak Badan Wakaf Nasional yaitu studi wakaf masih perlu perbaikan kembali, karena sejauh ini beberapa masukan yang tertera pada tesis atau disertasi menyebutkan bahwa; pertama, Pengelolaan wakaf hanya sebatas pada aspek ritual keagamaan, sehingga wakaf tidak berkembang dengan baik. Kedua, Pengetahuan nazir akan pengelolaan tanah wakaf masih rendah sehingga tanah wakaf yang ada belum maksimal dimanfaatkan. Ketiga, Banyaknya tanah wakaf yang tidak memiliki sertifikat sehingga tanah wakaf tersebut masih belum bisa digunakan.(Fauziah, 2016)

e. Menetukan sebuah bingkai waktu dan bagaimana cara untuk mengukur keberhasilan, pasang target-target untuk mencapai tujuan termasuk tanggal dan siapa yang bertanggung jawab dan memonitoring. Mengenai jadwal dan sejenisnya ini, tidak ada penjadwalannya. Ketika terjadi kasus atau sengketa baru melakukan sidak dan pemeriksaan lainnya.

Dari penjabaran di atas, dapat dilihat bahwa dalam manajemen perencanaan secara tertulis memang sudah ada, hal ini bisa kita lihat dari undang-undang wakaf, penetapan visi misi yang tertuang dalam peraturan BWI maupun dalam Web Page BWI. Namun dalam hal pelaksanaan perencanaan ini belum dievaluasi, terlihat dari banyaknya permasalahan wakaf yang terjadi baik dari hasil penelitian terdahulu maupun dari pengamatan lapangan. Sehingga perlu diadakan evaluasi mendetail yang dimulai dari aspek Nadzir wakaf yang merupakan ujung tombak dalam pengelolaan wakaf, sehingga bisa dipetakan perencanaan yang sesuai dengan tujuan wakaf dan fakta di masyakat Indonesia.

Pengorganisasian meliputi masing-masing pihak diberikan tugas terpisah, membentuk bagian, mendelegasikan dan menetapkan sistem komunikasi, serta setiap karyawan dikordinir dalam satu tim yang solid dan terorganisir (George R. Terry dan Leslie W. Rue, 2019). Pada hakikatnya pengorganisasian ialah proses penyusunan struktur organisasi yang sesuai dengan sasaran, sumber daya yang dimiliki, dan lingkungan yang melingkupinya. Pengorganisasian 
sebagai salah satu fungsi manajemen merupakan sistem kerjasama beberapa orang yang dilaksanakan dengan pembidangan dan pembagian seluruh pekerjaan atau tugas, dengan membentuk sejumlah satuan kerja yang menghimpun pekerjaan dalam satu unit kerja.

Sistem kepengerusan Badan Wakaf Indonesia sudah dibentuk sedemikian rupa dari tingkat nasional hingga tingkat kecamatan. Hal ini bisa kita lihat dari setruktur tingkat nasional yang memiliki beberapa divisi sebagai berikut:(B. W. Indonesia, 2020)

a. Dewan Pertimbangan

b. Badan Pelaksana

c. Divisi Kelembagaan, Tata Kelola, dan Advokasi

d. Divisi Pembinaan dan Pemberdayaan Nadzir

e. Divisi Humas, Sosialisasi, dan Literasi wakaf

f. Divisi Pengelolaan dan Pemberdayaan wakaf

g. Divisi Pendataan dan Sertifikasi Wakaf

h. Divisi Kerjasama, Penelitian dan Pengembangan

Selain struktur yang sudah dibentuk, tugas dan wewenang BWI juga sudah ditegaskan dalam pasal 49 Ayat 1 UU Nomor 41 Tahun 2004, sebagai berikut:

a. Melakukan pembinaan terhadap nadzir dalam mengelola dan mengembangkan harta benda wakaf

b. Melakukan pengelolaan dan pengembangan harta benda wakaf berskala nasional dan intenasional

c. Memberikan persetujuan dan/atau izin atas perubahan peruntukan dan status harta benda wakaf

d. Memberhentikan dan mengganti nadzir

e. Memberikan persetujuan atas penukaran harta benda wakaf

f. Memberikan saran dan pertimbangan kepada pemerintah dalam penyusunan kebijakan dalam perwakafan.

Dari struktur serta tugas dan wewenang BWI pada tingkat nasional, sudah dirancang sedemikian rupa untuk mencapai Visi dan Misi BWI. Selain itu Pada tingkat Daerah, BWI juga sudah membentuk departemen yang menangani perwakafan tingkat regional yaitu pada BWI tingkat Kabupaten, Kota dan dibantu juga oleh Kantor Wilayah Kementrian Agama pada departemen Bidang Penerangan Agama Islam, Zakat dan Wakaf. Pada tingkat kecamatan juga ada perwakilan BWI yang juga dibantu oleh PPAIW (Pejabat Pembuat Akta Ikrar Wakaf) yang terletak di setiap Kantor Urusan Agama pada setiap kecamatan.

Namun pada pengurus tingkat kecamatan belum ada pembagian tugas yang signifikan. Sedangkan petugas rata-rata sudah double job sehingga kurang efektif dalam mengurus lembaga ini. Hal ini bisa kita lihat dari PPAIW (Pejabat Pembuat Akta Ikrar Wakaf), selain sebagai PPAIW kebanyakan petugas juga merupakan pengurus di KUA kecamatan, kemudian Nadzir wakaf, Nadzir juga bukan sebagai pekerjaan utama, melainkan profesi sampingan saja. Padahal Nadzir dan PPAIW ini merupakan ujung tombak dari pelaksanaan wakaf, sehingga kedua profesi ini seharusnya mendapat perhatian dari pemerintah untuk menunjang terlaksananya pengelolaan wakaf yang sesuai dengan amanat Undang-Undang.

Selain itu, menurut Rahmat Dahlan bahwa ikrar wakaf dalam perundangan belum adanya ketegasan yang memberikan jaminan wakif atau ahli warisnya berhak untuk 
melakukan pengawasan dan meminta pertanggungjawaban nazhir pengelolaan wakaf. Terutama wakaf uang (Dahlan, 2016).

Dengan demikian, ini menegaskan bahwa belum ada kejelasan dalam tanggung jawab pekerjaan pengelolaan wakaf. Sehingga merasa bahwa buan tanggung jawab nazir atau lembaga. Terlihat profesi nazir sebagai sampingan, belum ada ketegasan dalam perundangundangan ataupun aturan.

Actuating diartikan pergerakan yang dapat mengarahkan seseorang untuk bekerja melakukan tanggung jawabnya. Dalam struktur organisasi Badan Wakaf Indonesia, fungsi pelaksanaan merupakan tugas dan wewenang dari Nadzir, hal ini sesuai dengan UU No 41 Tahun 2004 Pasal 11 yang menyatakan bahwa Nazhir mempunyai tugas sebagai berikut: melakukan pengadministrasian harta benda wakaf, mengelola dan mengembangkan harta benda wakaf sesuai dengan tujuan, fungsi, dan peruntukannya, mengawasi dan melindungi harta benda wakaf, dan melaporkan pelaksanaan tugas kepada Badan Wakaf Indonesia.(R. Indonesia, 2004) Dalam pelaksanaannya Nadzir dibantu oleh PPAIW (Pejabat Pembuat Akta Ikrar Wakaf) yang membantu dalam hal pencatatan dan penghubung antara Nadzir dan Wakif.

Kegiatan pengelolaan wakaf tersebut sudah dilakukan dalam lembaga ini, namun kurang efektif dilakukan. Terlihat dari beberapa artikel menyatakan bahwa Pengetahuan nadzir akan pengelolaan tanah wakaf masih rendah, dan juga dipertegas diartikel oleh Imam Wahyudi Indrawan dimuat dalam website Badan Wakaf Indonesia menuliskan bahwa nazhir wakaf masih belum profesional dan kreatif dalam mengelola aset wakaf. Hal ini terlihat dari banyaknya masjid dan aset-aset wakaf lainnya yang terbengkalai.(B. W. Indonesia, 2020) Dengan demikian, kegiatan dalam mengarahkan nazhir bertujuan bertanggung jawab masih belum dilaksanakan. Sebagaimana juga di pertegas oleh Ifa Hanifia Senjiati menyatakan bahwa janji wakaf yang belum sepenuhnya dilakukan oleh Nadzir, pelaporan keuangan Wakaf dimiliki belum dilaporkan. Pelaporan yang dilakukan dalam penelitian ini hanya pelaporan administrasi. Ini menunjukkan bahwa manajemen aset wakaf tidak efektif dan efisien (Senjiati, Malik, Ridwan, \& Irwansyah, 2020)

Selain itu bisa dilihat juga dari beberapa penelitian terdahulu seperti penelitian oleh Nurul Hak, bahwa pengelolaan wakaf di Bengkulu pada umumnya masih dikelola secara tradisional, Kendatipun ada yang dikelola secara profesional produktif, hanya ada beberapa lokasi, namun disayangkan data-data pengelolaan tanah wakaf yang dilakukan secara produktif tersebut tidak pernah ada laporannya di Kementerian Agama Kota Bengkulu (Hak, 2019). Kemudian penelitian oleh Nilsa Susilawati, diketahui bahwa dalam pengelolaan wakaf hanya ada 5 orang Nadzir dari 18 Nadzir yang melaksanakan tugas pengelolaan wakaf yang sesuai dengan amanat Undang-undang (Susilawati \& Guspita, 2019).

Selain dari beberapa penelitian di atas, fakta di lapangan juga menunjukkan bahwa pengelolaan aset wakaf ini belum optimal, hal ini terlihat dari banyaknya tanah wakaf yang belum tersertifikasi. Dari hasil wawancara, sertifikasi tanah wakaf ini terkendala oleh biaya bagi tanah yang harus ada pemecahan sertifikat, kemudian juga bagi nadzir perorangan, biaya pengelolaan wakaf ini merupakan faktor yang menghambat dalam pengembangan aset wakaf terutama tanah.(Herawati, 2020)

Dari temuan peneliti dan penelitian terdahulu, bisa kita lihat bahwa pelaksanaan wakaf ini belum terselenggara secara efektif. Untuk itu masih memerlukan perbaikan mulai dari organisasi tingkat atas, hingga organisasi wakaf tingkat bawah, yaitu Nadzir yang merupakan 
ujung tombak pengelolaan wakaf. Bagi nadzir diperlukan pelatihan dan sertifikasi nadzir, agar nadzir yang terdaftar adalah nadzir yang profesional dan sudah mendapatkan legalitas dari BWI. Sehingga bisa diprioritaskan nadzir yang fokus dalam pengelolaan wakaf, buka nadzir yang diposisikan sebagai profesi sampingan saja. Selain itu juga diperlukan bantuan biaya dalam pengelolaan aset wakaf, hal ini juga menunjang proses pengelolaan wakaf bagi nadzir perorangan serta membantu biaya sertifikasi bagi tanah wakaf yang memerlukan proses pemecahan sertifikat.

Supaya tujuan perusahaan tercapai dilakukanlah proses pengevaluasi suatu perushaan dan mengoreksi tindakan-tindakan. Kegiatan tersebut disebut pengawasan(Abdullah, 2013). Belum adanya pengaturan secara tegas yang memberikan jaminan wakif atau ahli warisnya berhak untuk melakukan pengawasan dan meminta pertanggungjawaban nazhir pengelolaan wakaf uang. Walaupun diatur, pengawasan terhadap perwakafan dilakukan oleh pemerintah dan masyarakat, baik aktif maupun pasif. Menurut Dahlan Undang-undang wakaf saat ini masih sekedar memberikan landasan hukum wakaf uang namun belum mendorong secara penuh bagi nazhir itu sendiri untuk menggembangkan dan mengelola aset wakaf (Dahlan, 2016). Padahal menurut Aden Rosadi dkk menyatakan dalam Undang-Undang Republik Indonesia Nomor 41 Tahun 2004 tentang Wakaf pasal 63 ayat 1-3 bahwa bimbingan dan pengawasan atas implementasi wakaf yg dilakukan oleh Menteri dengan melibatkan Dewan Wakaf Indonesia (BWI) dan mempertimbangkan saran-sarannya dengan pertimbangan Dewan Indonesia Ulama (MUI).(Rosadi, Effendi, \& Busro, 2018). Dengan begitu bahwa pengawasan sebenarnya di atur dalam perundangan yaitu menteri dan dewa wakaf Indonesia serta MUI.

Namun, faktanya dilapangan masih belum terealisasi perihal tersebut. Menurut Edi Setiawan bahwa pengawasan dilakukan masih secara manual saja, seperti hanya konfirmasi secara lisan dan juga tidak memiliki panduan SOP. Ketua nazhir pun tidak memantau secara langsung untuk melihat kinerja nazhir yang bertanggung jawab pada wakaf tersebut. Bukan hanya itu, masyarakat pun juga hanya percaya terhadap nazhir karena menganggap mereka seorang kiai (Setiawan, 2016) .

Selanjutnya, belum ada ketegasan mengenai pengawasan wakaf ini juga menimbukan dampak bagi pengelolaan tanah wakaf. Hal ini bisa dibuktikan dengan mewawancarai pegawai Baznas di Yogyakarta menyatakan bahwa banyaknya tanah wakaf yang terbengkalai, tidak dimanfaatkan secara optimal. Kemudian banyak tanah wakaf yang tidak diurus sertifikat wakafnya dan dilaporkan kembali ke petugas PPAIW. Tidak adanya sertifikat wakaf ini memperbesar potensi terjadinya sengketa tanah wakaf yang sering terjaadi dimasyarakat. Sehingga aturan yang tegas mengenai pengawasan wakaf ini sangat diperlukan.

Kemudian sistem kontrol merupakan perihal yang akan meninjau operasi dan memutuskan tindakan yang diambil supaya tujuan tercapai. Dalam hal ini, sistem kontrol membutuhkan pemahaman tentang persyaratan untuk kinerja yang baik. Selain itu kinerja yang bagus digambarkan sebagai kemampuan pribadi untuk memperoleh tujuan dan sebagai bahan pertimbangan yg sedang diselesaikan. Ini diikuti oleh umpan balik dari informasi yang diungkapkan dalam prinsip bahwa "motivasi untuk mencapai tujuan cenderung berkembang ketika menginformasikan tentang apa yg terjadi. Dengan kata lain, kesadaran akan hal itu dapat menghasilkan kinerja yang optimal. (Shulthoni et al., 2018). Praktek yang dapat kita lakukan dalam pengawasan ini, bisa dilihat di negara Malaysia. Negara ini mengatur pengawasannya di setiap unit/cabang di setiap daerah. Daftar cabang tersedia di situs web Lembaga Wakaf. Cabang ditunjuk berdasarkan aplikasi dan harus memenuhi indeks kinerja utama (KPI) (Iqmal, Kamaruddin, Masruki, \& Hanefah, 2018). Dengan seperti ini jika di 
terapkan di Indonesia, pengawasan terhadap zakat makin optimal, karena sudah memiliki kemampuan dalam kinerja di bidang wakaf dan bisa di kontrol setiap cabang atau perdaerah lembaga wakaf.

\section{Simpulan}

Berdasarkan hasil penelitian yang sudah dipaparkan dapat diketahui bahwa. Pengelolaan wakaf di Badan Wakaf Indonesia dari aspek Manajemen Planning, Organizing, Actuating, dan Controlling, belum berjalan secara optimal. Hal ini terlihat dari aspek Planning yang belum bisa mencapai Visi dan Misi BWI dengan optimal dikarenakan masih terdapat berbagai permaslahan. Aspek Organizing, pada tingkat nasional sistem kepengurusan dan pembagian tugas sudah disusun sedemikian rupa, begitupun juga pada tingkat daerah dan kecamatan. Namun pada tingkat kecamatan, kepengurusan wakaf belum menjadi pekerjaan utama. Pada aspek Actuating, pelaksanaan pengelolaan wakaf belum terlaksana secara optimal, hal ini terlihat dari berbagai permasalahan yang ditemukan baik dari penelitian maupun dari fakta di lapangan. Pada aspek Controlling, belum terlaksana dengan baik, karena sistem pengawasan yang jarang dilakukan serta hanya melalui lisan yang tidak dibarengi dengan mensurvei langsung ke lapangan. Sehingga pengelolaan wakaf ditinjau dari aspek POAC, masih memerlukan perbaikan-perbaikan supaya dapat tercapainya Visi dan Misi Badan Wakaf Indonesia 


\section{DAFTAR PUSTAKA}

Abdullah, D. dan. (2013). Pengantar Ilmu Manajemen dan Komunikasi. Jakarta: Prestasi Pustaka Publisher.

Agama, K. (2020). Sistem Informasi Wakaf Kemenag.

Dahlan, R. (2016). Análisis Kelembagaan Badan Wakaf Indonesia. ESENSI, 6(1), 121. https://doi.org/10.15408/ess.v6i1.3125

Dakhi, Y. (2016). Implementasi POAC terhadap Kegiatan Organisasi dalam Mencapai Tujuan Tertentu. Jurnal Warta, 53(9), 1679-1699.

Direktorat Jenderal Bimbingan Masyarakat Islam. (2012). Manajemen Pengelolaan Zakat. Jakarta.

Fauzi, A. (2014). Penyelesaian Sengketa Hak atas Tanah Wakaf dI Luar Pengadilan Oleh Kepala Dusun (Studi Kasus di Kecamatan Semidang Alas Maras Kabupaten Seluma Provinsi Bengkulu). Retrieved February 27, 2020, from Universitas Bengkulu website: http://repository.unib.ac.id/9960/

Fauziah, A. (2016). Fenomena Wakaf Di Indonesia: Tantangan Menuju Wakaf Produktif. Jakarta: Badan Wakaf Indonesia.

George R. Terry dan Leslie W. Rue. (2019). Dasar-dasar Manajemen. jakarta: Bumi Aksara.

Hak, N. (2019). Potensi Wakaf Dan Pengelolaan Di Bengkulu. Jurnal BAABU AL-ILMI: Ekonomi Dan Perbankan Syariah, 3(2). https://doi.org/10.29300/ba.v3i2.1535

Herawati, M. (2020). Wawancara PPAIW. Kota Bengkulu.

Huda, N., Rini, N., Mardoni, Y., Anggraini, D., \& Hudori, K. (2016). Manajemen Pengelolaan Wakaf di Indonesia Timur. Ekuitas: Jurnal Ekonomi Dan Keuangan, 20(01).

Indonesia, B. W. (2018). Perundang-Undangan.

Indonesia, B. W. (2020). Badan Wakaf Indonesia. Retrieved from Badan Wakaf Indonesia website: https://www.bwi.go.id

Indonesia, P. R. Wakaf., (2004).

Indonesia, R. Undang-Undang Republik Indonesia Nomor 41 Tahun 2004 Tentang Wakaf. , (2004).

Iqmal, M., Kamaruddin, H., Masruki, R., \& Hanefah, M. M. (2018). Waqf Management Practices: Case Study in a Malaysian Waqf Institution. World Journal of Social Sciences, 8(3), 1-12. Retrieved from https://www.researchgate.net/publication/328133339

Jubaedah. (2017). Dasar Hukum Wakaf. Tazkiya Jurnal Keislaman, Kemasyarakatan \& Kebudayaan, 18(2), 255-270.

Kamal, M. (2019). Konsep Dasar Dan Evolusi Pemikiran Manajemen. PROSIDING SEMINAR INTERNASIONAL "Tantangan Manajemen Pendidikan Islam, Hukum Islam Dan Bahasa Melayu Di Era Revolusi 4.0,” 351-362.

Khusaeri, K. (2015). Wakaf Produktif. Al-A'raf: Jurnal Pemikiran Islam Dan Filsafat, 12(1), 77. https://doi.org/10.22515/ajpif.v12i1.1185

Kompas.com. (2019). Potensi Besar, Wakaf Produktif Belum Tersosialisasi dengan Baik. Retrieved February 29, 2020, from Kompas.com website: https://money.kompas.com/read/2019/09/27/201410426/potensi-besar-wakaf-produktif- 
belum-tersosialisasi-dengan-baik

Mappasiara, M. (2018). Manajemen Strategik Dan Manajemen Operasional Serta Implementasinya Pada Lembaga Pendidikan. Idaarah: Jurnal Manajemen Pendidikan, 2(1), 74-85. https://doi.org/10.24252/idaarah.v2i1.5116

Moerti, W. (2019). Bagikan Sertifikat Tanah Wakaf, Jokowi Cerita Saat Lahan Masjid Jadi Sengketa. Retrieved from Merdeka.com website: https://www.merdeka.com/peristiwa/bagikan-sertifikat-tanah-wakaf-jokowi-cerita-saatlahan-masjid-jadi-sengketa.html

Nizar, M. (2018). Prinsip-Prinsip Manajemen Syariah (Studi Pengembangan Koperasi Syariah Fatayat NU Kecamatan Purwodadi Kabupaten Pasuruan). 4(2), 114-129.

Rosadi, A., Effendi, D., \& Busro, B. (2018). The Development of Waqf Management Throught Waqf Act in Indonesia (Note on Republic of Indonesia Act Number 41 of 2004 regarding Waqf). Madania: Jurnal Kajian Keislaman, 22(1), 1. https://doi.org/10.29300/madania.v22i1.881

Sarinah. (2017). Pengantar Manajemen. Yogyakarta: Deepublish.

Senjiati, I. H., Malik, Z. A., Ridwan, I. L., \& Irwansyah, S. (2020). Management of Waqf Assets at Waqf Institutions in Indonesia. 409(SoRes 2019), 297-302. https://doi.org/10.2991/assehr.k.200225.062

Setiawan, E. (2016). Pengelolaan Wakaf Pondok Pesantren Al-Hikmah Sirampog Kabupaten Brebes. Inferensi, 10(2), 495. https://doi.org/10.18326/infsl3.v10i2.495-516

Shulthoni, M., Saad, N. M., Kayadibi, S., \& Ariffin, M. I. (2018). Waqf Fundraising Management: a Proposal for a Sustainable Finance of the Waqf Institutions. Journal of Islamic Monetary Economics and Finance, 3, 201-234. https://doi.org/10.21098/jimf.v3i0.776

Suhairi. (2015). Implementasi Fungsi-Fungsi Manajemen Dalam Pengelolaan Wakaf Produktif. Akademika, 20(01).

Susilawati, N., \& Guspita, I. (2019). Implementasi Tugas Nazhir Dalam Pengelolaan Harta Wakaf Berdasarkan Undang-Undang No. 1 Tahun 2014 Di Kecamatan Kaur Utara Kabupaten Kaur. Al-Intaj: Jurnal Ekonomi Dan Perbankan Syariah, 5(2), 269. https://doi.org/10.29300/aij.v5i2.2073 